McQuillen, K. (1958). J. gen. Microbiol. 18, 498-512

\title{
Lysis Resulting from Metabolic Disturbance
}

\author{
By K. McQUILLEN
}

Department of Biochemistry, University of Cambridge

When a suitable environment is maintained, there is every reason to expect that a bacterial culture can continue to grow indefinitely. Each part of each cell will increase in a balanced manner until division results in reproduction of the cellular unit. There is no evidence that a resting phase is necessary nor that a bacterial cell must sooner or later die. If a cell divides, then it cannot be said to die unless both of the progeny succumb since there is no indication of a mother-and-daughter relationship in bacterial reproduction. That individual cells do die may at present be interpreted in terms of chance or rather mischance-a local adverse condition (as in the 'spontaneous' induction of a lysogenic organism). In an unsuitable medium, growth may continue for a time or it may stop more or less abruptly; further, in each case the cells of the culture may remain in a state of suspended animation or they may rapidly lyse. A medium may be unsuitable by virtue of chemical or physical factors; or the presence of enzymes, viruses or bacteriocines; or factors which cause metabolic disturbance such as the absence of adequate nutrients or the presence of inimical drugs. This paper is concerned with lysis caused by metabolic disturbance.

The bacterial cell consists of a protoplast surrounded by a strong and rigid cell wall which maintains the form of the cell. The protoplast includes the cytoplasm and the nuclear apparatus (chromatinic body) and is bounded by a fragile protoplast membrane (cytoplasmic membrane, plasma membrane) which is the osmotic barrier of the cell. Lysis is said to occur when the structural integrity of the cell is destroyed. It can be observed macroscopically when a turbid suspension clears or microscopically when individual cells are seen to disintegrate, lose their density or change their staining characteristics. Thus it involves some change in the cell wall and/or protoplast membrane since these are the structures which maintain the form of the cell and the integrity of its internal constituents. Often the progress of lysis, like that of growth, is followed turbidimetrically. Alternatively, the leakage of intercellular substances into the surrounding medium can be studied. Changes which occur on the outside of individual bacterial cells can be investigated quantitatively by the method of micro-electrophoresis.

In order to define the nature of lysis it is necessary to know something of the composition and structure of the components involved, the cell wall and the protoplast membrane (see Fig. 1). Bacterial cell walls may comprise about $\mathbf{2 5} \%$ of the dry weight of the cell and appear to be composed of mucopolysaccharide in Gram-positive organisms and this, together with lipoprotein in Gram-negative bacteria (see review by Work, 1957). The mucopolysaccharide 
usually contains $\mathrm{N}$-acetylated hexosamine and muramic acid (3-O- $\alpha$-carboxyethyl-hexosamine), one or more of the sugars, glucose, galactose, mannose, arabinose and rhamnose, and the amino acids, glutamic acid, and alanine together with lysine or diaminopimelic acid (DAP) and sometimes glycine or aspartic acid and traces of others. Where the point has been investigated it has been found that much of the glutamic acid and some of the alanine is of the D-configuration, the lysine L, and the DAP, meso- or LL. In Gram-negative bacteria the walls contain, in addition, up to $20 \%$ lipid and also protein of conventional amino acid composition.

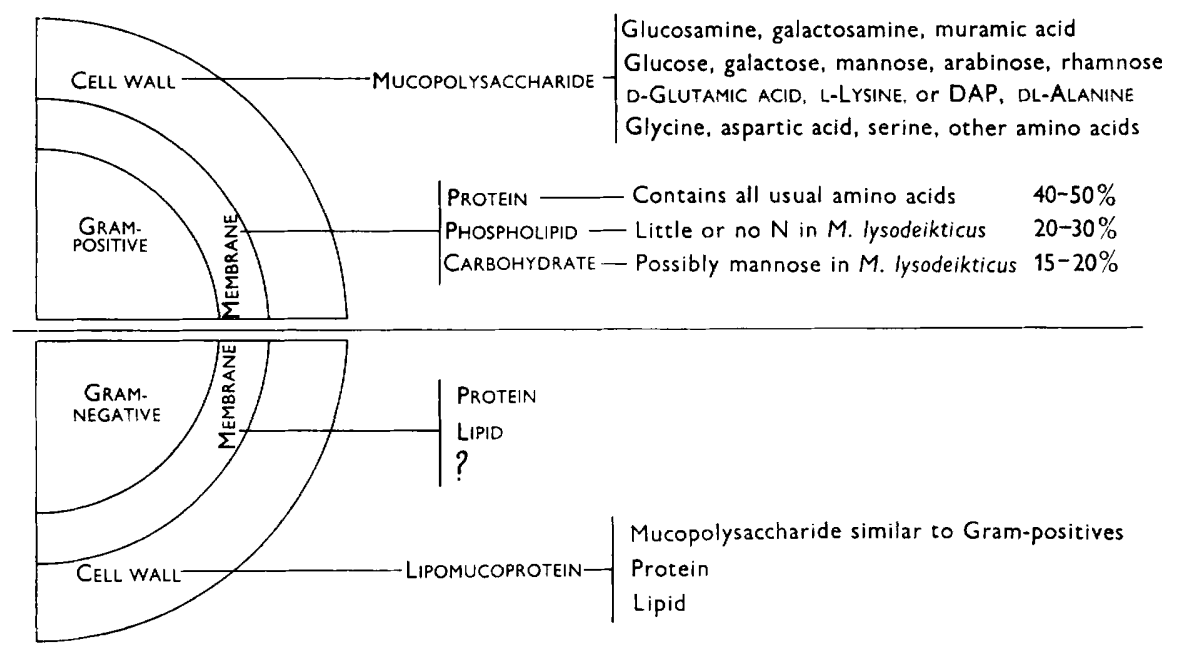

Fig. 1. Probable constitution of cell walls and protoplast membranes of Grampositive and Gram-negative bacteria. (Data from several sources, see text.)

The protoplast membrane accounts for about $10 \%$ of the dry weight of the cell and is usually considered to be lipoprotein, though few analyses have been made. That of Staphylococcus aureus is reported to be about $40 \%$ protein and $\mathbf{2 2 . 5} \%$ lipid (Mitchell \& Moyle, 1956). The membrane of Bacillus megaterium is dissolved by lipase but not by ribonuclease, although it is claimed to contain $11 \%$ ribonucleic acid (Vennes \& Gerhardt, 1956). However, this figure is based solely on an orcinol reaction estimation which indicates only the presence of pentose. The protoplast membrane of Micrococcus lysodeikticus was found by Gilby \& Few (personal communication) to contain $28 \%$ lipid-mainly phospholipid of very low nitrogen content but also some carotenoid. The same membranes have been investigated by the writer who found $50 \%$ protein (containing most of the usual amino acids) and about $16 \%$ reducing sugar probably mainly mannose. Glucose, the only hexose present in the cell wall of $\boldsymbol{M}$. lysodeikticus was absent and the hexosamine content was about $2.5 \%$ as compared with $16 \%$ for cell wall (McQuillen, unpublished observations). This reveals an unsuspected carbohydrate component of the protoplast membrane.

We will now consider specific instances of metabolic disturbance which can be rationalized in terms of what is known of the structures involved. 


\section{Unbalanced growth resulting from nutritional deficiency}

Thymine deficiency in Escherichia coli. Strain 15 $_{\mathrm{T}}$ of $E$. coli requires thymine for normal growth, and omission of this substance from an otherwise adequate medium causes the organism to lose the power to form colonies at the rate of $c .90 \%$ /generation time. This 'thymineless death' is accompanied by increase in turbidity of the culture, increase in length and diameter of the cells, and a doubling of the protein and ribonucleic acid (Cohen \& Barner, 1954, 1956). The metabolic disturbance results in continued cytoplasmic growth without equivalent nuclear increase (for which thymine is required) and although this leads to rapid death it does not engender lysis.

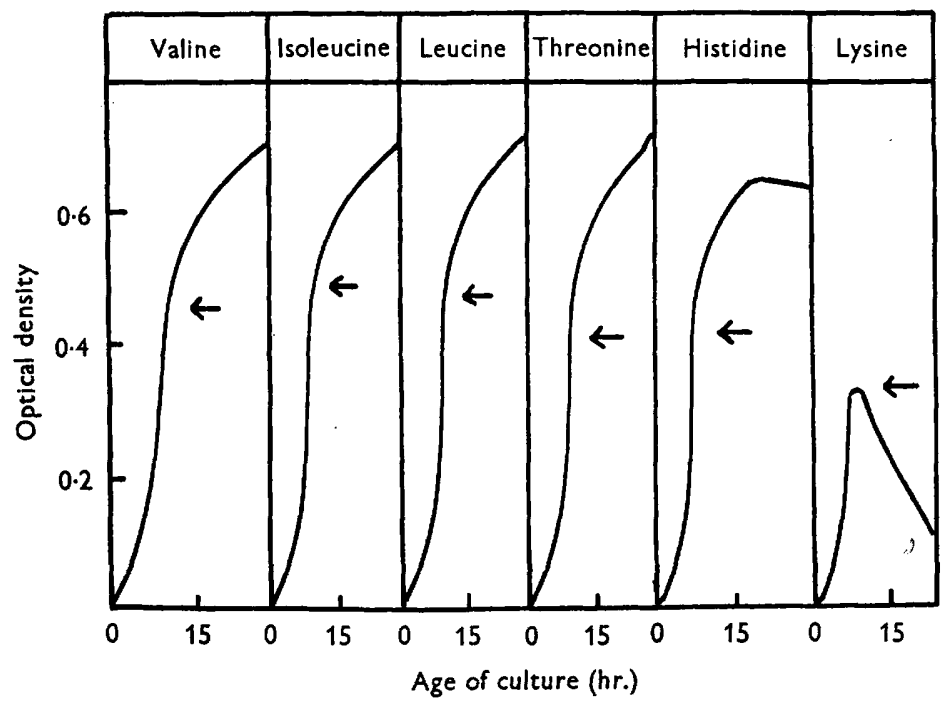

Fig. 2. Growth curves of Streptococcus faecalis 9790 in media limited by various amino acids. Arrows indicate where limiting amino acid is exhausted. (Data of Toennies \& Shockman, 1953.)

Valine deficiency in Streptococcus faecalis. Strain 9790 of $S$. faecalis is exacting towards the amino acids, threonine, leucine, isoleucine, valine, methionine, arginine, histidine and lysine. Toennies and colleagues have studied the effects of limiting growth by each of these independently (Toennies \& Gallant, 1949 $a, b$; Toennies \& Shockman, 1953; Shockman, Kolb \& Toennies, $1957 a, b)$. Only in the case of lysine limitation did lysis occur immediately after all the amino acid had been assimilated (see below). In all other cases there was a substantial increase in turbidity of the culture even after the limiting amino acid had been exhausted (Fig. 2). The effects of valine have been studied in more detail (Shockman et al. 1957a). After the medium was depleted of valine, growth of the culture ceased to be exponential but the optical density increased by a further $50 \%$. The dry weight of the cells went up by about $30 \%$, although the total $\mathrm{N}$ was little changed. However, the cell-wall fraction which in the exponential phase accounted for $13 \%$ of the 
total N, had increased to represent $24 \%$. Moreover, of the cellular amino acids only lysine had altered appreciably (increase of $27 \%$ ) and lysine, together with glutamic acid and alanine, is a constituent of the cell wall, whereas valine and the other amino acids are not. Rhamnose and glucosamine, two compounds present almost exclusively in the wall, were also found to have nearly doubled in amount during the post-exponential phase. It would seem that limitation of valine (and possibly several other amino acids) results in unbalanced growth such that while cellular protein cannot be synthesized, bacterial cell wall can continue to be formed and may almost double in amount. As with limitation of nuclear development this does not, however, lead to lysis.

Lysine deficiency in Streptococcus faecalis. When with the same strain 9790 of $S$.faecalis, lysine was the limiting amino acid, growth was exponential until all the amino acid had been used and then rapid lysis occurred (Toennies \& Gallant, $1949 b$ ). The requirements for onset of lysis were reported to be: (a) depletion of lysine from the medium; $(b)$ a $\mathrm{pH}$ value near neutrality; $(c)$ high concentration of phosphate $(0 \cdot 3 \mathrm{M})$. Recently, the matter has been re-investigated with some interesting developments (Shockman et al. 1957b): $(a)$ cells need not be taken from lysine-depleted media; when taken from the exponential phase they are 'lysis-prone' whether lysine or valine would ultimately limit growth. (b) Cells grown at lower $\mathrm{pH}$ values can be induced to lyse when the $\mathrm{pH}$ is raised. (c) High phosphate concentration is not essential for lysis: it can occur in lysine-free phosphate buffer growth medium or more rapidly in $\mathbf{0 . 3} \mathrm{M}$-phosphate buffer or in $\mathrm{M}-\mathrm{NaCl}$. However, lysis does not occur in distilled water.

Briefly the situation can be summarized as follows: Streptococcus faecalis, strain 9790, when removed from the exponential phase of growth or at the end of growth limited by lysine deficiency (but not other amino acids) shows a marked tendency to lyse in salt or buffer solutions of $\mathrm{pH}$ value near neutrality. Should growth be limited by an amino acid such as valine which, unlike lysine, is not a component of the cell wall, then after the exponential phase there follows a period during which cell-wall material increases without increase in cytoplasmic protein.

Diaminopimelic acid deficiency in Escherichia coli. Lysis caused by amino acid limitation has also been studied by Meadow \& Work (1956), Meadow, Hoare \& Work (1957) and by Rhuland (1957). Meadow used three mutant strains of $E$. coli ACTC 9637: 26-26 which requires lysine, 173-25 which has an absolute requirement for diaminopimelic acid (DAP) and is stimulated by further addition of lysine, and $\mathrm{D}$ (derived from 173-25) which requires DAP but is not stimulated by lysine. It is probable that in $E$. coli lysine is normally formed by decarboxylation of DAP:

\section{$\mathrm{COOH} . \mathrm{CHNH}_{2} \mathrm{CH}_{2} \mathrm{CH}_{2} \mathrm{CH}_{2} \mathrm{CHNH}_{2} \mathrm{COOH} \rightarrow$ $\mathrm{CH}_{2} \mathrm{NH}_{2} \mathrm{CH}_{2} \mathrm{CH}_{2} \mathrm{CH}_{2} \mathrm{CHNH}_{2} \mathrm{COOH}+\mathrm{CO}_{2}$.}

The lysine-requiring mutant 26-26 grew well in minimal media +lysine and showed no tendency to lyse. Mutant $D$ behaved in the same way when DAP was added to the basal medium. However, when mutant 173-25 was grown in 
media containing excess lysine but limiting DAP, lysis of the culture began immediately after attainment of maximum optical density. Moreover, a similar sequence of events followed when mutant $\mathbf{D}$ was grown in adequate medium +lysis. The lysine of mutant 173-25 was prevented by addition of lanthionine to media containing lysine and DAP or by replacing the lysine by $\alpha-N$-acetyl lysine. Rhuland (1957) showed that lysis of mutant 173-25 in limiting DAP was a function of the lysine concentration and that it could be overcome by adding more DAP.

As a result of the findings of Meadow \& Work (1956), it was apparent that it might be possible to obtain Escherichia coli deficient or wholly lacking in cell wall (i.e. protoplasts) by DAP limitation. It was already known that in Bacillus megaterium DAP is present as a structural component only in the cell wall and that removal of the wall by controlled digestion with lysozyme yields protoplasts still having most of the attributes of living organisms (McQuillen, 1956). Dr Meadow kindly agreed to collaborate with the writer in an attempt to see whether or not lysis of the mutant 173-25 in media deficient in DAP was due to formation of protoplasts followed by lysis of these fragile structures. Using continuous phase-contrast microscopy of micro-colonies in droplets of media suspended from a cover glass and immersed in liquid paraffin, we were able to watch DAP-limited $E$. coli develop into spherical forms which subsequently lysed to leave 'ghosts' of the same shape (McQuillen \& Meadow, 1956, unpublished observations mentioned in Meadow et al. 1957). It is possible but not certain that these spherical forms which are osmotically sensitive are devoid of cell wall.

More recently, the writer has been able to obtain stable preparations of spherical and near-spherical form by growing heavy suspensions of Escherichia coli 173-25 in media lacking DAP but containing $20 \%$ sucrose to give osmotic support (see Pl. 1). This technique is analogous to that used by Lederberg (1956) for obtaining 'protoplasts' of $\boldsymbol{E}$. coli by penicillin treatment (see below). Bauman \& Davis (1957) have independently shown that DAP-deprivation gives rise to 'protoplasts' of the same mutant of $E$. coli.

\section{Unbalanced growth resulting from drug action}

Antibiotics, including chloramphenicol. It is now well established that chloramphenicol inhibits the synthesis of protein in many species of bacteria. The inhibition is more or less immediate and can result in unbalanced increase of components such as nucleic acids and capsular material (Gale \& Folkes, 1953; Hahn, Wisseman \& Hopps, 1954; Wisseman, Smadel, Hahn \& Hopps, 1954) without concomitant formation of protein. It has recently been suggested that in Escherichia coli the nucleic acid formed in the presence of chloramphenicol is abnormally unstable and rapidly breaks down on removal of the antibiotic (Neidhardt \& Gros, 1957). However, physiologically active deoxyribonucleic acid can be formed in phage-infected bacteria in the presence of chloramphenicol (Hershey \& Melechen, 1957) and the ribonucleic acid formed in Staphylococcus aureus treated with chloramphenicol seems to play a role in the subsequent formation of protein when the drug is removed (Gale \& Folkes, 
1953). Whatever its mode of action, it is true to say that in general chloramphenicol does not cause rapid lysis of bacteria.

That there is no immediate change in the surface structures is also shown by micro-electrophoresis studies. The effects of a range of antibiotics on Staphylococcus aureus were determined in washed suspensions and in growing cultures

Table 1. Effect of antibiotics on washed suspensions of Staphylococcus aureus

Electrophoretic mobilities determined in phosphate buffer $(0 \cdot 003 \mathrm{M}, \mathrm{pH} 7 \cdot 3)$, containing glucose (1 mg. $/ \mathrm{ml}$.) and, where indicated, antibiotic (100 $\mu \mathrm{g} . / \mathrm{ml}$.). (Data of McQuillen, 1950, unpublished.)

Antibiotic

\section{None}

Oxytetracycline

Chlortetracycline

Chloramphenicol

Penicillin

Bacitracin

Streptomycin
Electrophoretic mobility ( $\mu . / \mathrm{sec} . /$ volt $/ \mathrm{cm}$.
$2 \cdot 68$
$2 \cdot 69$
$2 \cdot 68$
$2 \cdot 66$
$2 \cdot 62$
$\mathbf{2 \cdot 7 4}$
$2 \cdot 07$

Table 2. Effect of antibiotics on growing cultures of

Staphylococcus aureus

Electrophoretic mobilities determined in phosphate buffer $(0 \cdot 003 \mathrm{M}, \mathrm{pH} \mathrm{7 \cdot 3})$ containing broth and, where indicated, antibiotic. (Data of McQuillen, 1950, unpublished.)

\begin{tabular}{|c|c|c|c|c|}
\hline \multirow[b]{2}{*}{ Antibiotic } & \multirow[b]{2}{*}{$\begin{array}{c}\text { Concentration } \\
(\mu \mathrm{g} . / \mathrm{ml} .)\end{array}$} & \multicolumn{3}{|c|}{$\begin{array}{l}\text { Electrophoretic mobility in } \\
\mu . / \mathrm{sec} / \mathrm{volt} / \mathrm{cm} \text {. after growth for }\end{array}$} \\
\hline & & $5 \mathrm{~min}$. & $30 \mathrm{~min}$. & $60 \mathrm{~min}$. \\
\hline None & - & $2 \cdot 07$ & $2 \cdot 10$ & 2.05 \\
\hline Oxytetracycline & 10 & $2 \cdot 11$ & $2 \cdot 11$ & $2 \cdot 10$ \\
\hline Chlortetracycline & 10 & $2 \cdot 06$ & 2.08 & $2 \cdot 05$ \\
\hline Chloramphenicol & 10 & $2 \cdot 05$ & $2 \cdot 08$ & $2 \cdot 04$ \\
\hline Penicillin & $\mathbf{1}$ & $1 \cdot 90$ & $1 \cdot 69$ & 1.55 \\
\hline
\end{tabular}

(McQuillen, 1950, unpublished observations). At $100 \mu \mathrm{g} . / \mathrm{ml}$. the only antibiotic which had an in vitro effect was streptomycin (Table 1), which was shown to adsorb to the surface of bacteria (McQuillen, $1951 b$ ). Growth of $S$. aureus for up to $60 \mathrm{~min}$. in chloramphenicol, chlortetracycline or oxytetracycline at $10 \mu \mathrm{g} . / \mathrm{ml}$. did not result in any detectable change in cell surface (Table 2). This can be contrasted with the action of penicillin (see below) which was apparent within a few minutes (McQuillen, 1951 a).

Penicillin. Although it has long been known that penicillin causes lysis of susceptible bacteria, there have been many theories about its mode of action; recently additional evidence has been obtained for one of these. Gardner (1940) discussed the morphological effects of penicillin and pointed out that Escherichia coli and other Gram-negative rods 'often showed grotesque giant forms due to autolytic swelling'. In staphylococci the 'change takes the form of spherical enlargement and imperfect fission'. Duguid (1946) wrote 'the morphological changes produced by the lower penicillin concentrations...the 
ready occurrence of swelling and protoplasmic protrusion, suggest that penicillin... interferes specifically with formation of the outer supporting cell wall, while otherwise allowing growth to proceed until the organism finally bursts its defective envelope and undergoes lysis'.

Many studies have shown that penicillin is bactericidal only when the organisms are in an environment in which growth can occur. McQuillen (1951 $a$ ) found that high concentrations of penicillin had no effect on the surface density of charge of Staphylococcus aureus and Escherichia coli suspended in buffer. In growth medium, or in buffer supplemented with a small amount of broth (1/100 dilution) addition of $0 \cdot 1$ unit penicillin $/ \mathrm{ml}$. initiated a change in the surface characteristics of $S$. aureus which could be detected within a few minutes; higher concentrations of penicillin provoked a similar change in $E$. coli. It was concluded that changes in the surface of susceptible bacteria were the earliest effects of penicillin then reported.

Although, by and large, Gram-positive bacteria are more sensitive to penicillin than are Gram-negative bacteria, the latter are by no means all resistant. Escherichia coli B, for instance, has an inhibition coefficient of $5 \mu \mathrm{g} . / \mathrm{ml}$. when growing in a glucose $+\mathrm{NH}_{3}+$ salts medium. Harrington (1954) surveyed the effects of penicillin on this organism. He found that after adding $5 \mu \mathrm{g}$. $/ \mathrm{ml}$. or more of the drug to a growing culture, the turbidity increased for 15-30 min. and then lysis ensued (Fig. 3). Neither protein nor nucleic acid synthesis was much affected during this pre-lytic period but the onset of lysis coincided with cessation of both, and with release into the medium of protein and $260 \mathrm{~m} \mu$.absorbing material which was not precipitable by trichloroacetic acid. The course of lysis could be followed by measuring the fluorescence on addition of $N$-tolyl- $\alpha$-naphthylamine-8-sulphonic acid, which combined with the released protein to form a fluorescent conjugate.

It was found that $\mathrm{Mg}^{++}$had a dramatic effect in preventing lysis. Addition of $0.02 \mathrm{M}-\mathrm{Mg}^{++}$to a culture inhibited by $5 \mu \mathrm{g}$. penicillin $/ \mathrm{ml}$. allowed normal increase of turbidity and prevented release of $260 \mathrm{~m} \mu$.-absorbing material for a $2 \mathrm{hr}$. period (Fig. 4). This protection was nullified by further addition of citrate and in the absence of additional $\mathrm{Mg}^{++}$, citrate enhanced the lytic effects caused by penicillin. Conversely, addition of $\mathrm{Mg}^{++}$to cells in the presence of citrate and penicillin afforded protection against lysis (Fig. 5). It is interesting that later Weibull (1956) reported that $0.01 \mathrm{M}-\mathrm{Mg}^{++}$preserved the integrity of protoplast membranes of Bacillus megaterium and that Lederberg (1956) found a high concentration of $\mathrm{Mg}^{++}$necessary for formation of stable 'protoplasts' of Escherichia coli by growth in broth containing penicillin (see below).

A striking demonstration of the necessity for growth before penicillin can exert its effect was also given by Harrington (1954). He showed that addition of an amount of chloramphenicol which just inhibited protein synthesis also prevented lysis caused by penicillin. Moreover, when lysis had begun it could be arrested by addition of chloramphenicol (Fig. 6). In these experiments it was also found that penicillin had no effect on nucleic acid synthesis in cells prevented from making protein by presence of chloramphenicol. 


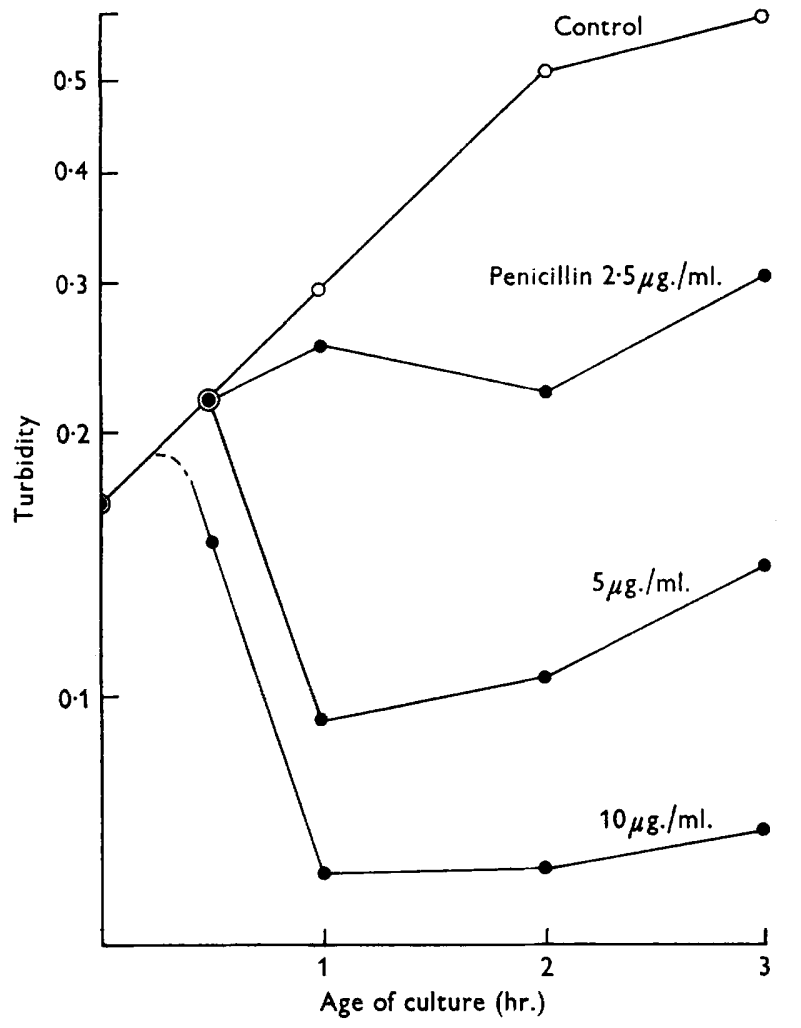

Fig. 3. Growth curves of Escherichia coli $B$ in the presence of $0,2 \cdot 5,5$ and $10 \mu \mathrm{g} . / \mathrm{ml}$. penicillin. (Data of Harrington, 1954.)
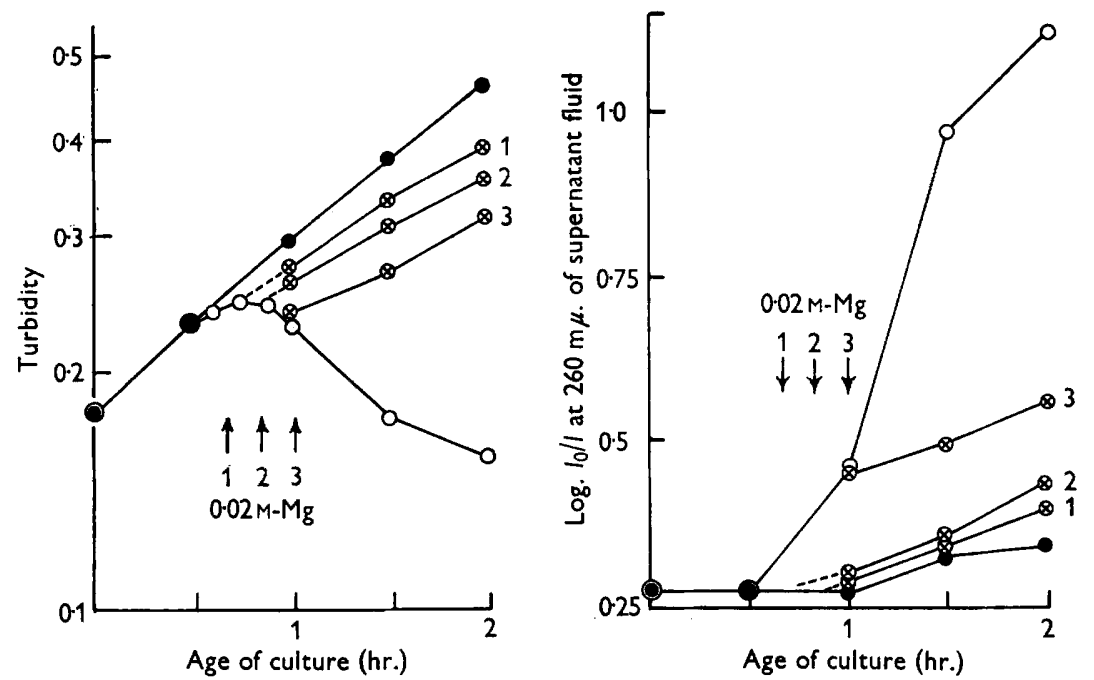

Fig. 4. Growth curves of Escherichia coli $B$ and release of $260 \mathrm{~m} \mu$.-absorbing material into supernatants of cultures. - Control; $\bigcirc-0,5 \mu \mathrm{g} . / \mathrm{ml}$. penicillin at time 0 ; $\otimes-\otimes, 5 \mu \mathrm{g} . / \mathrm{ml}$. penicillin at time 0 and $0.02 \mathrm{M}-\mathrm{Mg}^{++}$added at time 40,50 or $60 \mathrm{~min}$. (Data of Harrington, 1954.) 
Three groups of workers (Lederberg, 1956; Liebermeister \& Kellenberger, 1956; Hahn \& Ciak, 1957) have now independently shown that under appropriate conditions, growth of Escherichia coli in the presence of penicillin can result in the formation of osmotically-fragile spherical bodies which resemble the protoplasts which can be obtained from certain Gram-positive bacteria by
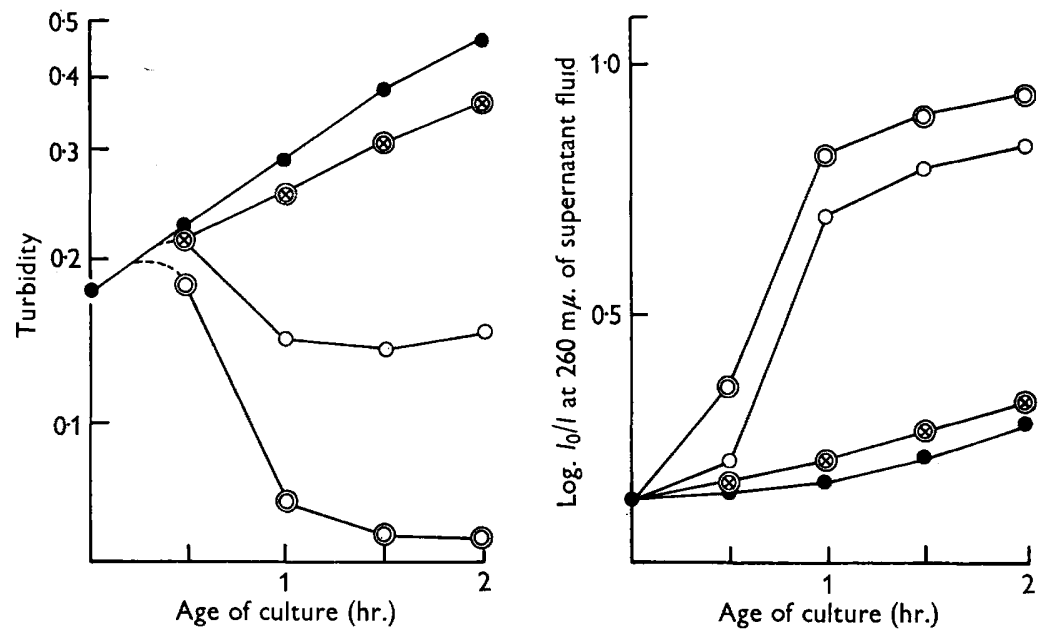

Fig. 5. Growth curves of Escherichia coli $B$ and release of $260 \mathrm{~m} \mu$-absorbing material into supernatant fluid of cultures. - Control; $\mathrm{O}-\mathrm{O}, 5 \mu \mathrm{g}$. penicillin $/ \mathrm{ml}$. at time 0 ; ()- (O, $5 \mu \mathrm{g}$. penicillin $/ \mathrm{ml}$. and 0.04 m-citrate at time 0 ; (8)-(8, $5 \mu \mathrm{g}$. penicillin $/ \mathrm{ml}$. and $0 \cdot 04 \mathrm{M}$-citrate at time 0 , followed by $0.03 \mathrm{M}-\mathrm{Mg}^{++}$at time $10 \mathrm{~min}$. (Data of Harrington, 1954.)

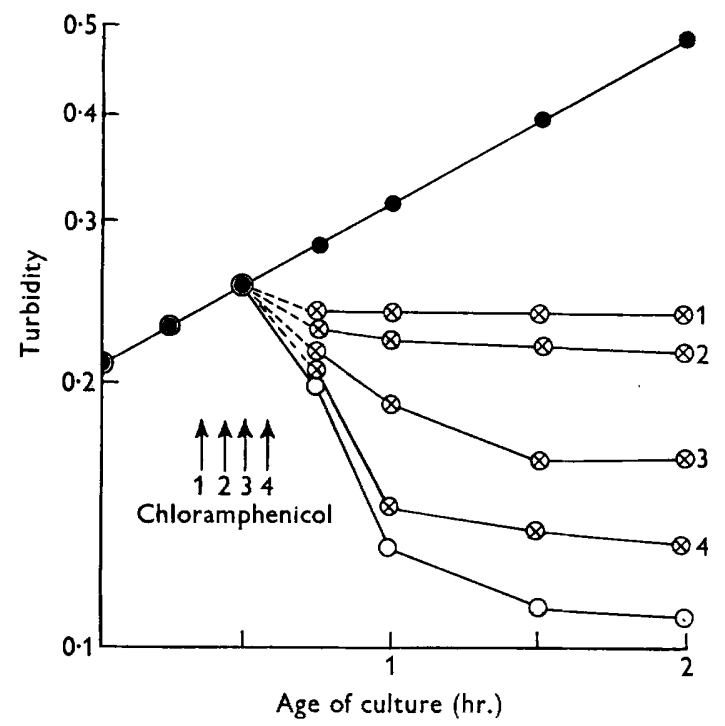

Fig. 6. Growth curves of Escherichia coli B. - - Control; $\bigcirc-O, 5 \mu \mathrm{g}$. penicillin $/ \mathrm{ml}$. at time $0 ; \otimes-\otimes, 5 \mu \mathrm{g}$. penicillin $/ \mathrm{ml}$. at time 0 and $10 \mu \mathrm{g}$. chloramphenicol $/ \mathrm{ml}$. added at time 20, 25, 30 or $35 \mathrm{~min}$. (Data from Harrington, 1954.) 
digestion of the cell wall with lysozyme (Weibull, 1956; McQuillen, 1956). A fully-grown broth culture of $\boldsymbol{E}$. coli is diluted about fourfold with fresh broth containing 100-1000 $\mu \mathrm{g}$. penicillin $/ \mathrm{ml} ., 20 \%$ sucrose and $0.2 \%$ magnesium sulphate. After aerated growth for $c .2 \mathrm{hr}$, the rods become converted into spherical 'protoplasts'. Dilution of the sucrose resulted in immediate lysis.

The writer has confirmed these findings and has also determined that the 'protoplasts' contain very much less DAP in their trichloroacetic acid-precipitable fraction than do intact cells of Escherichia coli. They resemble quite

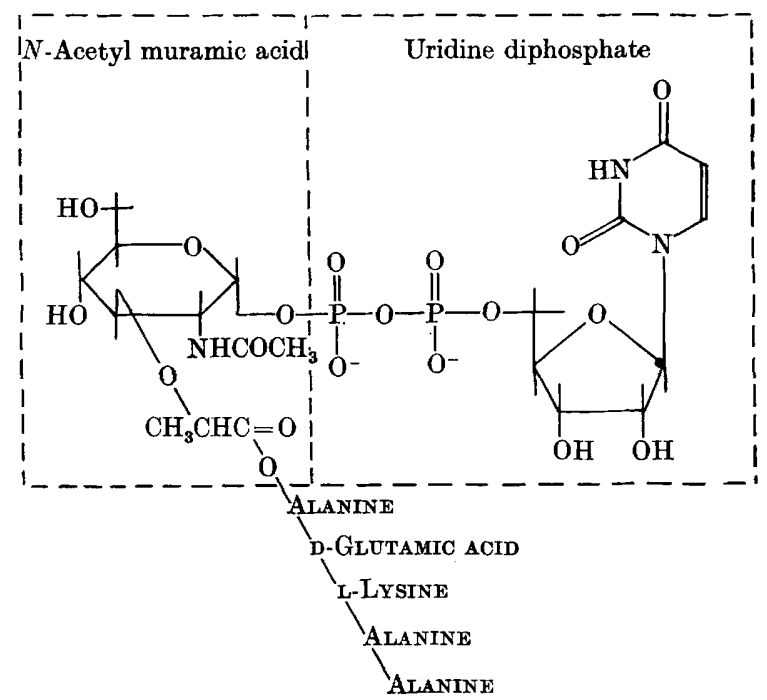

Fig. 7. Suggested constitution of uridine nucleotide which accumulates when Staphylococcus aureus grows in the presence of penicillin. (After Park \& Strominger, 1957.)

remarkably the 'protoplasts' of $E$. coli formed by deprivation of DAP (see Pl. 1). There is, however, still no certainty that the entire cell wall is absent from these Gram-negative 'protoplasts' and the unqualified term protoplast should not be used until this is established.

A biochemical interpretation of many of the above findings has recently been assembled by Park \& Strominger (1957). Park (1952) had found that treatment of Staphylococcus aureus with penicillin resulted in the accumulation of uridine nucleotides, including one linked to a peptide containing alanine, glutamic acid and lysine. It is now suggested that the structure of this nucleotide might be as shown in Fig. 7. The cell wall of $S$. aureus has also been analysed and shown to contain several of the same components and in the same relative proportions as in this nucleotide (Table 3). The substances common to both are $N$-acetyl-muramic acid (the 'unknown amino sugar' present in the cell walls of many bacterial species), D-glutamic acid, L-lysine and DL-alanine. Park \& Strominger (1957) suggest that the uridine nucleotide is an intermediate in cell-wall synthesis and that penicillin prevents its utilization, and this 'interferes with the maintenance of the cell wall or its synthesis'. 
Table 3. Comparison of analyses of cell wall and a uridine nucleotide which accumulates in penicillin-treated Staphylococcus aureus

The data are from Park \& Strominger (1957) and are expressed as approximate relative molar proportions.

\begin{tabular}{lcc}
\multicolumn{1}{c}{ Component } & Cell wall & Uridine \\
nucleotide
\end{tabular}

\section{DISCUSSION}

A number of examples of metabolic disturbance have been described and it is clear that only in some is lysis an early consequence. It is possible to restrict nuclear development while allowing protein and ribonucleic acid to increase and, equally, it is possible to prevent protein synthesis while allowing nucleic acid and cell-wall formation to continue; in neither case does lysis necessarily result. Other derangements, however, result either in 'protoplast' formation or in lysis, depending on whether or not osmotic protection is afforded by, for example, solutions of high sucrose concentration. In these cases it seems that lysis is a direct result of the failure of the cell wall to support the osmotic barrier (the protoplast membrane). It is likely that in all the cases described above, lysis results from an active process of unbalanced growth of cytoplasm.

In the case of the mutant of Escherichia coli which requires DAP and lysine (173-25) restriction of DAP in the presence of adequate lysine will prevent cell-wall synthesis while allowing continued cytoplasmic protein synthesis. On the other hand, mutant $\mathrm{D}$ which needs only DAP and can derive its lysine from DAP, will have a source of the cell-wall component (DAP) and of lysine for its protein so long as any DAP remains (Fig. 8). Thereafter, it can make neither cell wall nor cytoplasmic protein. The situation is altered, however, when exogenous lysine is supplied. In this case cytoplasmic protein can increase after cell-wall formation is limited by exhaustion of DAP. Thus lysis might be expected and was found. The inhibition of lysis of $E$. coli mutants 173-25 and $\mathrm{D}$ by addition of lanthionine to media containing lysine and limiting DAP, results in a growth response qualitatively and quantitatively very similar to that of mutant $D$ in the absence of lysine and lanthionine. This might be explained if lanthionine were found to inhibit the utilization of exogenous lysine. It was inferred by Meadow et al. (1957) that lanthionine does not inhibit DAP decarboxylation* because cystine does not and because both substances inhibit the growth of DAP-requiring mutants competitively in the absence of lysine. This might indicate also an inhibition of utilization of endo-

* This has now been confirmed experimentally (Dr Meadow, personal communication). 
genously formed lysine. The finding that the lysine-requiring mutant 26-26 of E. coli does not lyse when lysine is limited is not surprising if this thesis of unbalanced growth be valid. Lysine is a component of both the cytoplasmic protein and the cell wall protein of $E$. coli and its restriction would not, a priori, be expected to allow continued formation of one rather than the other (Fig. 8).

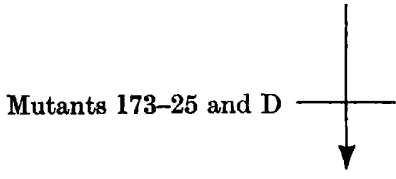

Diaminoptmelic acid

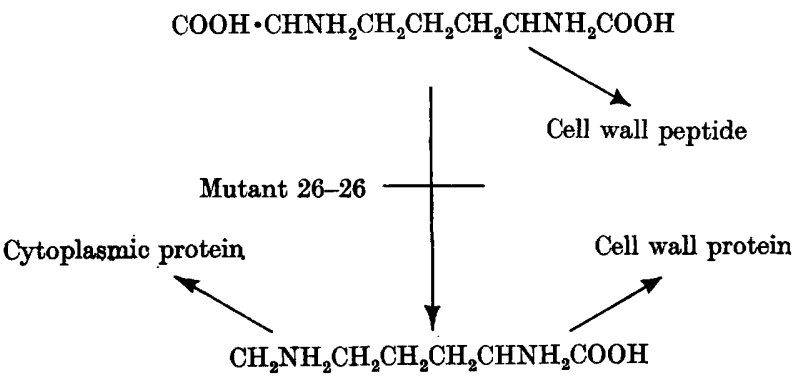

LYSINE

Fig. 8. Interrelationships and functions of diaminopimelic acid and lysine in Escherichia coli, ACTC 9637, and its mutants. Mutant 26-26 requires lysine, mutant $D$ requires diaminopimelic acid, and mutant $173-25$ has an absolute requirement for diaminopimelic acid and a partial requirement for lysine.

The situation with the Gram-positive Streptococcus faecalis is rather different. Here the cell wall is simpler in constitution; there is little lipid and no protein. The peptide component of the mucopolysaccharide contains only a few amino acids among which are D-glutamic acid, D- and L-alanine and L-lysine. Limitation of growth by an amino acid not present in the wall (e.g. valine) apparently allows excess wall synthesis after cytoplasmic protein synthesis ceases. (It is puzzling that Shockman et al. (1957a) did not find an increase in the glutamic acid and alanine as well as in lysine during the postexponential phase.) When, on the other hand, lysine is restricted, lysis ensues. However, it was found that cells taken from the exponential phase of growth in valine-limited media were also prone to lyse. This is similar behaviour to that observed in Staphylococcus aureus by Mitchell \& Moyle (1957). Indeed the isolated walls of this organism are reported to undergo autodigestion. It cannot be said from the evidence available whether or not in the case of $S$. faecalis an autolytic process is involved-possibly a running backwards of reactions normally concerned in cell-wall synthesis. This may be a somewhat general phenomenon in cells taken from the phase of most rapid growth. Certainly organisms are known to produce enzymes which degrade cell walls, e.g. Bacillus subtilis (Nomura \& Hosoda, 1956; Richmond, 1957). On the other hand, it 
appears significant that only with lysine-limited $S$. faecalis does lysis follow immediately after maximum culture density is reached and that lysine is one of the few amino acids present in the cell wall.

The action of penicillin in causing lysis of Gram-positive and Gram-negative organisms depends on the occurrence of growth or, more specifically, of protein synthesis. Under such conditions there is a change in the nature of the surface of the cells within a few minutes of the addition of the drug. In the case of Staphylococcus aureus there accumulates a compound containing muramic acid and amino acids which is believed to be a precursor of part of the cell wall. Although the cell walls of Gram-negative organisms are more complex, that of Escherichia coli contains muramic acid, glucosamine, alanine, glutamic acid and diaminopimelic acid. These substances are specifically released from the cell wall by the action of bacteriophage (Weidel, this Discussion) suggesting that they occur as a structural unit.

Several Gram-negative bacteria can be converted, by growth in media of high osmotic pressure in the presence of penicillin, into protoplast-like forms in which the cell wall is either absent or weakened. In the case of Escherichia coli these appear almost identical to the 'protoplasts' formed by DAP-deprivation. Protoplasts of Bacillus megaterium entirely lacking cell wall are capable of protein and nucleic acid synthesis, enzyme formation, bacteriophage growth and even growth and division (McQuillen, 1956). They can, moreover, synthesize DAP, although they excrete it (or a derivative) rather than incorporate it into cell wall. The protoplast-like forms of $\boldsymbol{E}$. coli have also been studied by the writer and have considerable synthetic abilities. They are able to increase in size and to synthesize enzymes. Lederberg (1956) reported that about half these protoplast-like forms are capable of reverting to rods in the absence of penicillin. It appears justified at present to conclude that the lysis caused by penicillin treatment results from an interference with cell-wall formation without concomitant cessation of certain other cellular activities. This unbalanced growth puts a stress on the protoplast membrane which it cannot withstand except in media of high osmotic pressure.

\section{REFERENCES}

Bauman, N. \& Davis, B. D. (1957). Selection of auxotrophic bacterial mutants through diaminopimelic acid or thymine deprival. Science, 126, 170.

Cohen, S. S. \& Barner, H. D. (1954). Studies on unbalanced growth in Escherichia coli. Proc. nat. Acad. Sci., Wash. 40, 885.

Cohen, S. S. \& Barner, H. D. (1956). Studies on the induction of thymine deficiency and the effects of thymine and thymidine analogues in Escherichia coli. J. Bact. 71,588 .

Duguid, J. P. (1946). The sensitivity of bacteria to the action of penicillin. Edinb. med. J. 53, 401.

Gale, E. F. \& Folkes, J. P. (1953). The assimilation of amino-acids by bacteria. 14. Nucleic acid and protein synthesis in Staphylococcus aureus; 15. Action of antibiotics on nucleic acid and protein synthesis in Staphylococcus aureus. Biochem. J. 53, 483, 493.

Gardner, A. D. (1940). Morphological effects of penicillin on bacteria. Nature, Lond. 146, 837. 
Hahn, F. E. \& Ciak, J. (1957). Penicillin-induced lysis of Escherichia coli. Science, $125,119$.

HahN, F. E., Wisseman, C. L. \& Hopps, H. E. (1954). Mode of action of chloramphenicol. II. Inhibition of bacterial D-polypeptide formation by an L-stereoisomer of chloramphenicol. J. Bact. 67, 674.

Harrington, M. G. (1954). The action of antibiotics on Bacterium coli. Dissertation presented to the National University of Ireland.

Hershey, A. D. \& Melechen, N. E. (1957). Synthesis of phage-precursor nucleic acid in the presence of chloramphenicol. Virology, 3, 207.

Lederberg, J. (1956). Bacterial protoplasts induced by penicillin. Proc. nat. Acad. Sci., Wash. 42, 574.

Liebermeister, K. \& Kellenberger, E. (1956). Studien zur L-Form der Bakterien. I. Z. Naturforsch. $11 b, 200$.

MCQuillen, K. $(1951 a)$. The bacterial surface. III. Effect of penicillin on the electrophoretic mobility of Staphylococcus aureus. Biochim. biophys. Acta, 6, 534.

McQuillen, K. (1951b). The bacterial surface. IV. Effect of streptomycin on the electrophoretic mobility of Escherichia coli and Staphylococcus aureus. Biochim. biophys. Acta, 7, 54.

MCQuillen, K. (1956). Capabilities of bacterial protoplasts. In Bacterial Anatomy, Symp. Soc. gen. Microbiol. 6, 127.

Meadow, P., Hoare, D. S. \& Work, E. (1957). Interrelationships between lysine and $\alpha \epsilon$-diaminopimelic acid and their derivatives and analogues in mutants of Escherichia coli. Biochem. J. 66, 270.

MEADOW, P. \& Work, E. (1956). Interrelationships between diaminopimelic acid, lysine and their analogues in mutants of Escherichia coli. Biochem. J. 64, 11 P.

Mitchell, P. \& Moyle, J. (1956). Osmotic function and structure in bacteria. In Bacterial Anatomy, Symp. Soc. gen. Microbiol. 6, 150.

Mitchell, P. \& Moyle, J. (1957). Autolytic release and osmotic properties of 'protoplasts' from Staphylococcus aureus. J. gen. Microbiol. 16, 184.

NeIdHardT, F. C. \& Gros, F. (1957). Metabolic instability of the ribonucleic acid synthesized by Escherichia coli in the presence of chloromycetin. Biochim. biophys. Acta, 25, 513.

Nomura, M. \& Hosoda, J. (1956). Action of an autolytic enzyme of Bacillus subtilis on the cell wall. Nature, Lond. 177, 1037.

PARK, J. T. (1952). Uridine-5'-pyrophosphate derivatives. I. Isolation from Staphylococcus aureus; II. A structure common to three derivatives; III. Aminoacid containing derivatives. J. biol. Chem. 194, 877, 885 and 897.

Park, J. T. \& Strominger, J. L. (1957). Mode of action of penicillin. Science, 125, 99.

Rhuland, L. E. (1957). Role of $\alpha, \epsilon$-diaminopimelic acid in the cellular integrity of Escherichia coli. J. Bact. 73, 778.

Richmond, M. H. (1957). Bacterial lysozyme. J. gen. Microbiol. 16, iv.

Shockman, G. D., Kols, J. J. \& Toennies, G. (1957a). Changes in the bacterial cell wall during growth. Fed. Proc. 16, 247.

Shockman, G. D., Kolb, J. J. \& Toennies, G. (1957 $b$ ). A study of spontaneous lysis of Streptococcus faecalis cells. Bact. Proc. p. 131.

Toennies, G. \& Gallant, D. L. (1949a). Bacterimetric studies. VI. The role of lysine in bacterial maintenance. J. biol. Chem. 177, 831 .

Toennies, G. \& Gallant, D. L. (1949b). Bacterimetric studies. V. Individual characteristics of the bacterial growth responses induced by different amino acids. Growth, 13, 21.

Toennies, G. \& Shockman, G. D. (1953). Quantitative amino acid assimilation in homofermentative metabolism. Arch. Biochem. Biophys. 45, 447.

VENNES, J. W. \& GERHARDT, P. (1956). Immunologic comparison of isolated surface membranes of Bacillus megaterium. Science, 124, 535. 
WeIBULl, C. (1956). Bacterial protoplasts; their formation and characteristics. In Bacterial Anatomy, Symp. Soc. gen. Microbiol. 6, 111.

Wisseman, C. L., Smadel, J. E., Hahn, F. E. \& Hopps, H. E. (1954). Mode of action of chloramphenicol. 1. Action of chloramphenicol on assimilation of ammonia and on synthesis of proteins and nucleic acids in Escherichia coli. J. Bact. 67, 662.

Wonk, E. (1957). Biochemistry of the bacterial cell wall. Nature, Lond. 179, 841.

\section{EXPLANATION OF PLATE}

Figs. 1-8. Phase-contrast photomicrographs of Escherichia coli $\mathbf{B}$ growing in broth containing sucrose $(15 \%, \mathrm{w} / \mathrm{v})$ and penicillin $(100 \mu \mathrm{g} . / \mathrm{ml}$.$) . Fig. 1$ at time 0 , figs. $2-4$ at times 60 to $90 \mathrm{~min}$., fig. 5 at time $120 \mathrm{~min}$., and figs. 6-8 at times 180 to $240 \mathrm{~min}$. Magnification, $\times 1000$.

Fig. 9. Phase-contrast photomicrograph of Escherichia coli 173-25 growing in broth containing sucrose $(15 \%, w / v)$ but no diaminopimelic acid (to which this mutant is exacting). The cells are similar to those in Fig. 1 at time 0 . Fig. 9 shows the appearance at time $180 \mathrm{~min}$. Magnification, $\times 1000$. 
Journal of General Microbiology, Vol. 18, No. 2

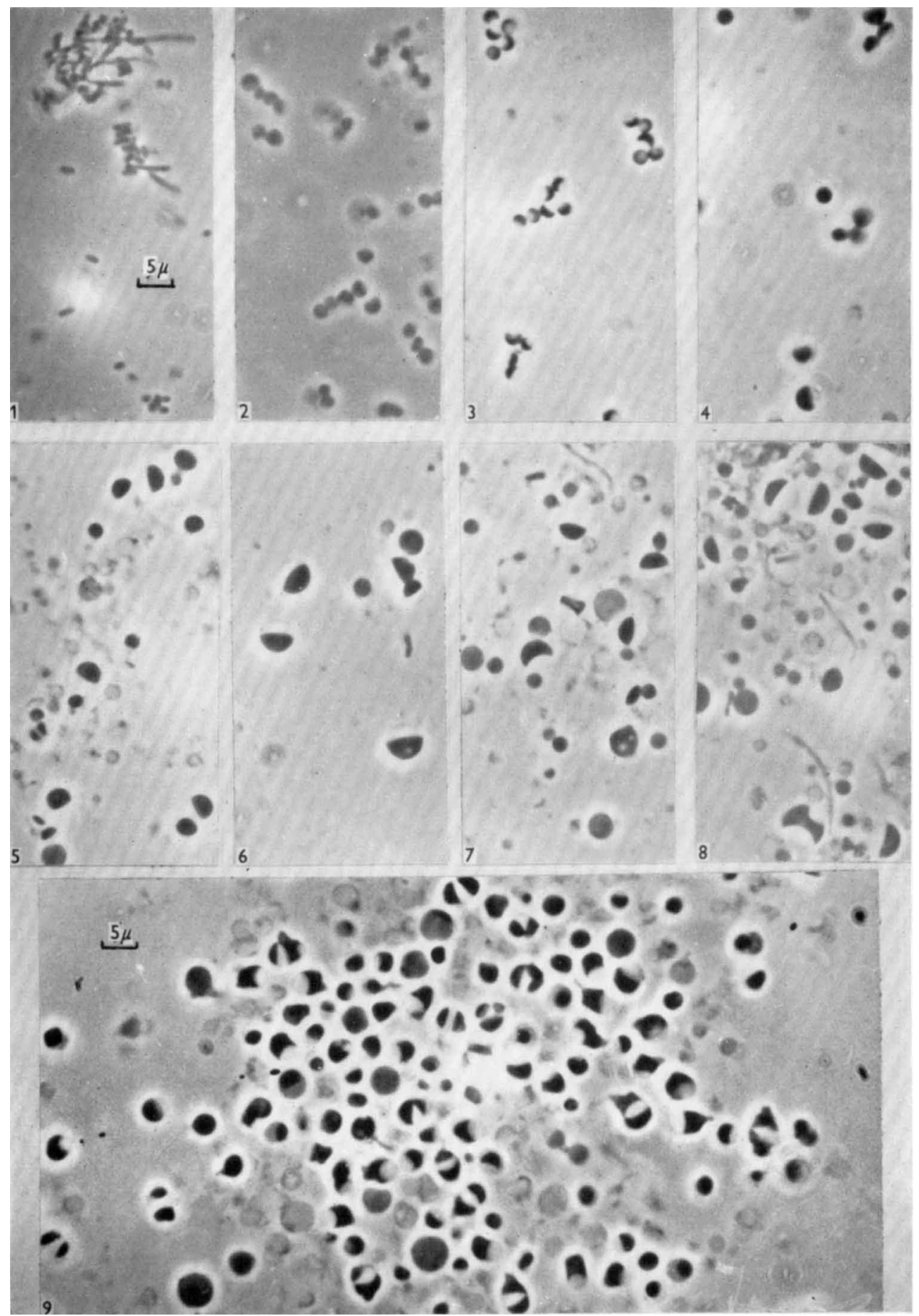

K. McQuillen--Lysis resulting firom metabolic disturbance. Plate 1

(Facing $p .512$ ) 